\title{
Regeneration and Transformation of Taro (Colocasia esculenta) with a Rice Chitinase Gene Enhances Resistance to Sclerotium rolfsii
}

\author{
Xiaoling $\mathbf{H e}^{1}$ \\ Hawaii Agriculture Research Center, 94-340 Kunia Road, Waipahu, HI \\ 96797
}

Susan C. Miyasaka²

University of Hawaii, Tropical Plant and Soil Science, 875 Komohana Street, Hilo, HI 96720

\section{Yi Zou ${ }^{1}$}

Indiana University, The Center for Genomics and Bioinformatics, 1001 E. Third Street, Bloomington, IN 47405

Maureen M.M. Fitch and Yun J. Zhu

Hawaii Agriculture Research Center, 94-340 Kunia Road, Waipahu, HI 96797

Additional index words. particle bombardment, disease resistance, genetic engineering, agricultural biotechnology, tropical root crop

\begin{abstract}
Genetic engineering has the potential to improve disease resistance in taro [Colocasia esculenta (L.) Schott]. To develop a method to produce highly regenerable calluses of taro, more than 40 combinations of Murashige and Skoog (MS) media at fullor half-strength with varying concentrations of auxin [ $\alpha$-naphthaleneacetic acid (NAA) or 2, 4-dichlorophenoxyacetic acid $(2,4-D)]$, cytokinin [benzyladenine (BA) or kinetin], and taro extract were tested for callus initiation and plant regeneration. The best combination, MS medium with $2 \mathrm{mg} \cdot \mathrm{L}^{-1} \mathrm{BA}$ and $1 \mathrm{mg} \cdot \mathrm{L}^{-1} \mathrm{NAA}$ (M5 medium), was used to produce regenerable calluses from taro $\mathrm{cv}$. Bun Long initiated from shoot tip explants. After 8 weeks of growth, multiple shoots from these calluses could be induced on MS medium with $4 \mathrm{mg} \cdot \mathrm{L}^{-1}$ BA (M15 medium). The rice chitinase gene (ricchi11) along with the neomycin phosphotransferase (npt II) selectable marker and $\beta$-glucuronidase (gus) genes were introduced into these taro calluses through particle bombardment. Transformed calluses were selected on M5 medium containing $50 \mathrm{mg} \cdot \mathrm{L}^{-1}$ geneticin (G418). Histochemical assays for beta-glucuronidase (GUS), polymerase chain reaction (PCR), reverse transcription-PCR, and Southern blot analyses confirmed the presence, integration, and expression of the rice chitinase gene in one transgenic line (efficiency less than $0.1 \%$ ). Growth and morphology of the transgenic plants appeared normal and similar to non-transformed controls. In pathogenicity tests, the transgenic line exhibited improved resistance to the fungal pathogen, Sclerotium rolfsii, but not to the oomycete pathogen, Phytophthora colocasiae.
\end{abstract}

Received for publication 15 Feb. 2010. Accepted for publication 7 May 2010.

This research was supported by the USDACSREES T-STAR program.

We thank Dr. Janice Uchida for assistance in isolating pathogens of taro. We also thank Drs. Uchida, Paul Moore, and Duane Bartholomew for their helpful suggestions to improve the manuscript.

The mention of a trademark, proprietary product, method, or vendor does not imply endorsement by the University of Hawaii, Hawaii Agriculture Research Center, or Indiana University nor its approval to the exclusion of other suitable products or vendors.

${ }^{1}$ Formerly with University of Hawaii, Department of Tropical Plant and Soil Sciences, 3190 Maile Way, Honolulu, HI 96822

${ }^{2}$ To whom reprint requests should be addressed; e-mailmiyasaka@hawaii.edu.
1970; Revill et al., 2005). Traditionally, taro is propagated vegetatively through suckers or stem cuttings (Plucknett et al., 1970). Viruses such as Dasheen mosaic virus (DsMV) are transmitted readily through vegetative planting materials. A protocol of shoot tip culture was developed to eliminate DsMV in taro (Hartman, 1974).

Diseases caused by fungi or oomycetes are among the most economically significant. Taro Leaf Blight is caused by the oomycete Phytophthora colocasiae, and yield losses of $25 \%$ to $95 \%$ are estimated in taro-growing countries (Brooks, 2000; Plucknett et al., 1970; Sharma et al., 2009). Southern blight is caused by the fungus Sclerotium rolfsii and is a problem in a large number of vegetable crops (Koike et al., 2006), including taro (Uchida et al., 2002).

Conventional breeding of taro is one method of improving disease resistance provided that naturally occurring resistance is found within the germplasm. Recently, new, commercial taro cultivars were bred with some resistance to the pathogen $P$. colocasiae (Cho et al., 2007; Trujillo et al., 2002). However, these cultivars need further improvement as a result of quality problems and breakdown of resistance under environmental conditions that are conducive to disease (R. Yamakawa, personal communications). Genetic engineering offers the potential of disease-resistant, transgenic taro lines that retain the same genetic composition of the original cultivars but with the addition of a few genes that confer disease resistance.

Considerable evidence indicates that plant chitinases are directly or indirectly associated with plant resistance to a wide range of fungal pathogens (Schlumbaum et al., 1986). Chitinases catalyze the hydrolysis of chitin, a major structural component of the cell walls of most fungi, insect exoskeletons, and crustacean shells (Gooday, 1990). Several important oomycete plant pathogens such as Phytophthora sp. and Pythium sp. are no longer classified as fungi. In addition to having diploid mycelial states, they have cell walls composed primarily of a mix of cellulosic compounds and glycan instead of chitin. Recently, Yan et al. (2008) used Fourier transform infrared spectroscopy to show that cell walls of Pythium aphanidermatum did contain chitin, although at half the level of fungal cell walls. Phytophthora zoospore germination was inhibited by chitinases (Young and Hwang, 1996), so perhaps the cell walls of these oomycetes also contain chitin.

Chitinase genes have been inserted into several plant species to significantly increase resistance to various fungal pathogens (Grison et al., 1996; Maximova et al., 2006). For example, rice transformed with a Class I rice chitinase gene, chill, showed increased resistance to the rice sheath blight pathogen, Rhizoctonia solani (Datta et al., 2000; Lin et al., 1995). Other researchers have enhanced disease resistance further in transgenic plants by combined expression of a chitinase gene with other pathogenesis-related (PR) protein genes (Jayaraj and Punja, 2007; Sridevi et al., 2008). These results provide strong evidence 
that insertion of chitinase genes alone or in combination with other $\mathrm{PR}$ protein genes have the potential to enhance disease resistance of crop plants without adversely affecting other important qualities.

Genetic transformation involves the insertion of transgenes into totipotent cells that are then regenerated into whole plants. A successful system of genetic transformation must include a method for production of totipotent cells such as those found in callus tissues and then a method of regeneration of whole plants. Various combinations and levels of phytohormones have been reported to produce regenerable calluses of taro (Deo et al., 2009; Malamug et al., 1992; Murakami et al., 1995). For example, Fukino et al. (2000) reported that callus of triploid taro cv. Eguimo was induced in Linsmaier and Skoog (LS) medium with $1 \mathrm{mg} \cdot \mathrm{L}^{-1} \alpha$-naphthaleneacetic acid (NAA), $2 \mathrm{mg} \cdot \mathrm{L}^{-1}$ benzyladenine (BA), and $3 \%$ sucrose. Then, calluses were transferred to hormone-free LS medium for regeneration of shoots. In contrast, Yam et al. (1990) found that half-strength Murashige and Skoog (1962) (MS) medium containing 5 $\mathrm{mg} \cdot \mathrm{L}^{-1} \mathrm{NAA}, 5 \mathrm{mg} \cdot \mathrm{L}^{-1} \mathrm{BA}$, and $25 \mathrm{mg} \cdot \mathrm{L}^{-1}$ taro extract (TE) produced callus in taro $\mathrm{cv}$. Akalomamale. This callus could then produce plantlets when transferred to hormone-free, half-strength MS medium with TE. Apparently, taro cultivars respond differentially to phytohormones, and it is necessary to test the various callus initiation media and shoot regeneration media on particular cultivars of interest.

There are only two reports in the literature of genetic transformation of taro (Fukino et al., 2000; He et al., 2008). Fukino et al. (2000) inserted the reporter gene $\beta$-glucuronidase (gus) using particle bombardment into triploid cv. Eguimo, which is one of the major taro cultivars grown in Japan. He et al. (2008) inserted a rice chitinase gene through Agrobacterium-mediated transformation into taro cv. Bun Long, which is a major commercial variety in Hawaii and the Dominican Republic.

Particle bombardment uses physical particles to introduce DNA into totipotent plant cells and then relies on DNA repair mechanisms that are common to all plants to ensure stable transgene integration. As a result, one major advantage of this method of genetic transformation is that it is not limited by cell type, species, or genotype (Altpeter et al., 2005).

In this study, we report the discovery of callus initiation media and shoot regeneration media to produce regenerable calluses in taro cv. Bun Long. To compare the two methods of genetic transformation, we inserted a rice chitinase gene through particle bombardment into taro. Pathogenicity tests of transgenic taro were conducted using both tissue-cultured plantlets and larger, acclimated potted plants. Results were compared with taro lines transformed through Agrobacterium.

\section{Materials and Methods}

Plant materials. Taro cvs. Bun Long and Maui Lehua were selected initially as plant materials, because they are among the most important, commercial taro cultivars in Hawaii. Cultivar Maui Lehua was used in studies on callus initiation. Cultivar Bun Long was used in all experiments.

Initiation of taro calluses. Shoot tips were excised under a microscope using the method of Hartman (1974) as the first step in producing DsMV-free plantlets. Multiple shoots were induced and tested using an enzymelinked immunosorbent assay for DsMV (Agdia Inc., Elkhart, IN) to determine the presence of the virus. All 10 shoot lines tested negative for DsMV, indicating that the procedure adapted from Hartman (1974) resulted in the elimination of the virus.

To develop a method to produce highly regenerable calluses, more than 40 callus initiation media containing MS (full-strength or half-strength) with varying combinations and concentrations of auxin [0 to $10 \mathrm{mg} \cdot \mathrm{L}^{-1}$ $\mathrm{NAA}$ or 0 to $9 \mathrm{mg} \cdot \mathrm{L}^{-1}$ 2,4-dichlorophenoxy- acetic acid (2,4-D)], cytokinin (0 to $15 \mathrm{mg} \cdot \mathrm{L}^{-1}$ BA or 0 to $8 \mathrm{mg} \cdot \mathrm{L}^{-1}$ kinetin), or taro extract (0 to $20 \mathrm{mg} \cdot \mathrm{L}^{-1} \mathrm{TE}$; Yam et al., 1990) were tested (Table 1). Types and concentrations of phytohormones were selected based on media reported to produce regenerable calluses of other taro cultivars (Fukino et al., 2000; Malamug et al., 1992; Murakami et al., 1995).

Media containing MS were autoclaved at $121{ }^{\circ} \mathrm{C}$ for $30 \mathrm{~min}$; then $20 \mathrm{~mL}$ was poured into 9-cm diameter petri dishes. Auxin NAA and cytokinin BA were added before autoclaving for appropriate treatments, whereas sterile-filtered 2,4-D and kinetin were added after autoclaving.

Six explants were placed on each plate containing callus initiation media and replicated five times, resulting in a total of 30 explants per media treatment. These explants were placed in the dark at $25{ }^{\circ} \mathrm{C}$ and periodically observed for production of callus. Dark conditions allowed maintenance of

Table 1. Over 40 combinations and concentrations of MS [full-strength (1), or half-strength (0.5)], auxin (NAA or 2, 4-D), cytokinin (BA or kinetin), taro extract (TE), or sucrose in media tested for initiation of calluses in both taro cultivars.

\begin{tabular}{|c|c|c|c|c|c|c|c|}
\hline Media no. & MS & $\begin{array}{c}\text { NAA } \\
\left(\mathrm{mg} \cdot \mathrm{L}^{-1}\right)\end{array}$ & $\begin{array}{c}2,4-\mathrm{D} \\
\left(\mathrm{mg} \cdot \mathrm{L}^{-1}\right)\end{array}$ & $\begin{array}{c}\mathrm{BA} \\
\left(\mathrm{mg} \cdot \mathrm{L}^{-1}\right)\end{array}$ & $\begin{array}{l}\text { Kinetin } \\
\left(\mathrm{mg} \cdot \mathrm{L}^{-1}\right)\end{array}$ & $\begin{array}{c}\mathrm{TE} \\
\left(\mathrm{mg} \cdot \mathrm{L}^{-1}\right)\end{array}$ & $\begin{array}{l}\text { Sucrose } \\
\left(\mathrm{mg} \cdot \mathrm{L}^{-1}\right)\end{array}$ \\
\hline$\overline{\mathrm{M} 0}$ & 1 & 0 & 0 & 0 & 0 & 0 & 0 \\
\hline M1 & 0.5 & 2 & 0 & 0.2 & 0 & 20 & 0 \\
\hline M2 & 0.5 & 0 & 0 & 1 & 0 & 20 & 0 \\
\hline M3 & 0.5 & 5 & 0 & 5 & 0 & 20 & 0 \\
\hline M4 & 1 & 5.5 & 0 & 0 & 0.2 & 0 & 0 \\
\hline M5 & 1 & 1 & 0 & 2 & 0 & 0 & 0 \\
\hline M6 & 1 & 5.5 & 0 & 2 & 0 & 0 & 0 \\
\hline M7 & 1 & 5.5 & 0 & 0 & 2 & 0 & 0 \\
\hline M8 & 1 & 1 & 0 & 0 & 0 & 0 & 0 \\
\hline M9 & 1 & 2 & 0 & 2 & 0 & 0 & 0 \\
\hline M10 & 1 & 1.5 & 0 & 2 & 0 & 0 & 0 \\
\hline M11 & 1 & 1 & 0 & 2 & 0 & 20 & 0 \\
\hline M12 & 1 & 0.5 & 0 & 1 & 0 & 0 & 0 \\
\hline M13 & 1 & 1 & 0 & 2 & 0 & 0 & 30 \\
\hline M14 & 1 & 0 & 0 & 2 & 0 & 0 & 0 \\
\hline M15 & 1 & 0 & 0 & 4 & 0 & 0 & 0 \\
\hline M16 & 1 & 0 & 0 & 8 & 0 & 0 & 0 \\
\hline M17 & 1 & 0 & 3 & 0.2 & 0 & 0 & 0 \\
\hline M18 & 1 & 0 & 6 & 0.2 & 0 & 0 & 0 \\
\hline M19 & 1 & 0 & 9 & 0.2 & 0 & 0 & 0 \\
\hline M20 & 1 & 0 & 0 & 0 & 0 & 0 & 0 \\
\hline M21 & 1 & 0.02 & 0 & 2 & 0 & 0 & 0 \\
\hline M22 & 1 & 0 & 1 & 0.2 & 0 & 0 & 0 \\
\hline M23 & 1 & 0 & 0.5 & 0.2 & 0 & 0 & 0 \\
\hline M24 & 1 & 0 & 3 & 0.2 & 0 & 0 & 0 \\
\hline M25 & 1 & 0 & 1 & 3 & 0 & 0 & 0 \\
\hline M26 & 1 & 0 & 2 & 0.2 & 0 & 0 & 0 \\
\hline M27 & 1 & 0 & 2 & 1 & 0 & 0 & 0 \\
\hline M28 & 1 & 0 & 2 & 2 & 0 & 0 & 0 \\
\hline M29 & 1 & 0 & 2 & 3 & 0 & 0 & 0 \\
\hline M30 & 1 & 5 & 0 & 0.2 & 0 & 0 & 0 \\
\hline M31 & 1 & 10 & 0 & 0.2 & 0 & 0 & 0 \\
\hline M32 & 1 & 0.5 & 0 & 2 & 0 & 0 & 0 \\
\hline M33 & 1 & 0.2 & 0 & 2 & 0 & 0 & 0 \\
\hline M34 & 1 & 0.2 & 0 & 1 & 0 & 0 & 0 \\
\hline M35 & 1 & 1.5 & 0 & 0 & 1 & 0 & 0 \\
\hline M36 & 1 & 0 & 0 & 10 & 0 & 0 & 0 \\
\hline M37 & 1 & 0 & 0 & 15 & 0 & 0 & 0 \\
\hline M38 & 1 & 0 & 1 & 1 & 0 & 0 & 0 \\
\hline M39 & 1 & 0 & 1 & 0 & 1 & 0 & 0 \\
\hline M40 & 0.5 & 0 & 1 & 1 & 0 & 0 & 0 \\
\hline M41 & 0.5 & 0 & 1 & 0 & 1 & 0 & 0 \\
\hline M42 & 1 & 0 & 1 & 0 & 2 & 0 & 0 \\
\hline M43 & 1 & 0 & 1 & 0 & 4 & 0 & 0 \\
\hline M44 & 1 & 0 & 1 & 0 & 8 & 0 & 0 \\
\hline
\end{tabular}

$\mathrm{MS}=$ Murashige and Skoog; NAA $=\alpha$-naphthaleneacetic acid; $\mathrm{BA}=$ benzyladenine; $\mathrm{TE}=$ taro extract. 
callus colonies in an undifferentiated state; under light, there is a tendency for induction of shoots.

Regeneration of shoots. If taro calluses were produced from the callus initiation media, then attempts to induce shoots were made by placing the calluses on various media under light (16-h photoperiod; $15 \mu \mathrm{mol} \cdot \mathrm{m}^{-2} \cdot \mathrm{s}^{-1}$ light intensity) at $25^{\circ} \mathrm{C}$. The media treatments consisted of: 1) the same medium used for callus initiation; 2) hormone-free, full-strength MS medium (M0); or 3) full-strength MS medium supplemented with 2,4 , or $8 \mathrm{mg} \cdot \mathrm{L}^{-1}$ BA (M14, M15, or M16, respectively).

Ten callus pieces $(\approx 40 \mathrm{mg}$ fresh weight per callus piece) were placed on each plate containing shoot initiation media and each media treatment was replicated six times, resulting in a total of 60 calluses per media. The number of shoots induced from each callus per media was recorded, and shoot morphology was observed daily.

Plasmid construct. The plasmid pBI121/ ricchill was sub-cloned using the rice chitinase gene with its own terminator and the cauliflower mosaic virus $35 \mathrm{~S}$ ( CaMV 35S) promoter as an insert and pBI121 as a vector at HindIII site (He et al., 2008). It contained the selection gene neomycin phosphotransferase (npt II); the reporter gene $\beta$-glucuronidase (gus) driven by the CaMV $35 \mathrm{~S}$ promoter (obtained from Clontech, Mountain View, CA; http://www.clontech.com); and the rice chitinase gene, ricchil1, with its own terminator driven by the $C a M V 35 \mathrm{~S}$ promoter (obtained from Dr. S. Muthukrishnan at Kansas State University).

Particle bombardment. Transformation of cv. Bun Long callus was conducted through particle bombardment using a method similar to Fukino et al. (2000). Soft yellowish white calluses that were grown on M5 medium were selected for particle bombardment. These calluses $(\approx 2 \mathrm{~g})$ were cut into small pieces and cultured in the center of a petri dish containing solid M5 medium at $25^{\circ} \mathrm{C}$ for $24 \mathrm{~h}$. Plasmids were coated onto 1.6- $\mu \mathrm{m}$ gold particles (Bio-Rad, Hercules, CA). Biolistic PDS$1000 / \mathrm{He}$ (Bio-Rad) was used to bombard calluses three times at a pressure of 1100 psi. A total of 30 plates was bombarded. After bombardment, the calluses were maintained on the same plates for $2 \mathrm{~d}$ in the dark at $25^{\circ} \mathrm{C}$ and then cut into $\approx 45$ pieces and transferred to fresh media $(\approx 9$ pieces per plate $)$ without antibiotics for $4 \mathrm{~d}$ in the dark at $25^{\circ} \mathrm{C}$.

Non-transformed calluses were placed in the dark on M5 medium with $50 \mathrm{mg} \cdot \mathrm{L}^{-1} \mathrm{G} 418$ (subcultured every $30 \mathrm{~d}$ ), and none survived after 90-d selection, indicating that growth of non-transformed cells was effectively suppressed. For selection of transformed cells, bombarded calluses were grown for $90 \mathrm{~d}$ in the dark on $50 \mathrm{mg} \cdot \mathrm{L}^{-1} \mathrm{G} 418$ with sub-culturing every $30 \mathrm{~d}$.

Polymerase chain reaction analysis. To determine the presence of the transgene, genomic DNA was extracted from $\approx 10 \mathrm{mg}$ of callus or leaf tissues and analyzed using polymerase chain reaction (PCR) based on the method described by He et al. (2008).
Histochemical GUS assay. The enzyme GUS histochemical assay was performed as described by He et al. (2008). The stem and leaf cuttings were observed for the characteristic blue precipitate that indicates GUS activity.

Reverse transcription-polymerase chain reaction analysis. To demonstrate the expression of the transgene, reverse transcription-PCR (RT-PCR) analysis was conducted as described by He et al. (2008). As a control, PCR was also conducted using total RNA without RT to confirm that the PCR product was derived from mRNA and not from the contaminating DNA.

Southern blot analysis. Total genomic DNA was isolated from fresh leaf tissue and $30 \mu \mathrm{g}$ of genomic DNA was digested overnight with the restriction enzyme BamHI to release a $1.9-\mathrm{kb}$ fragment containing the ricchillgene, which was flanked by two BamHI sites. Southern blot analysis was conducted according to the method described in $\mathrm{He}$ et al. (2008).

To reveal the copy numbers of the transgene, genomic DNA was extracted from shoot tissues and $20 \mu \mathrm{g}$ of DNA was digested with the enzyme EcoRI that has a single digestion site in the T-DNA. Southern blot analysis was conducted as described by $\mathrm{He}$ et al. (2008).

Pathogenicity with Phytophthora colocasiae. In a laboratory test for disease resistance, the positive transgenic line was rapidly propagated by transferring to Magenta boxes (PhytoTechnologies Laboratories, Shawnee Mission, $\mathrm{KS})$ with liquid M15 multiplication medium. After emergence of roots, transgenic and nontransgenic plantlets with three to five leaves were transferred from Magenta boxes to $5-\mathrm{cm}$ diameter pots containing a peat-based potting medium. The plantlets were placed in an environmentally controlled chamber (Conviron E8 chamber; Controlled Environments, Inc., Pembina, ND) maintained at $25^{\circ} \mathrm{C}$ with a $16-\mathrm{h}$ photoperiod at a photon flux density of 590 $\mu \mathrm{mol} \cdot \mathrm{m}^{-2} \cdot \mathrm{s}^{-1}$.

After $\approx 40 \mathrm{~d}$ of growth, they were transferred to $10-\mathrm{cm}$ diameter pots containing a peat-based potting medium and grown for an additional $30 \mathrm{~d}$. The average height of these plants was $40 \mathrm{~cm}$, and the average leaf blade dimensions were $12 \mathrm{~cm}$ in width and $16 \mathrm{~cm}$ in length. Healthy, second or third leaf blades were selected for this bioassay (in which the first leaf blade is the youngest fully expanded one).

This bioassay was based on the method of Schenck (personal communications). Phytophthora colocasiae was cultured on a 10\% V8 agar medium (Miller, 1955) for 1 to 2 weeks to produce active sporangia. A 4-mm diameter plug containing active $P$. colocasiae spores was placed onto the upper surface of a leaf blade that remained attached to the whole plant. Disease severity was evaluated using the diameter of the lesion on the infected leaf blade at 2, 4, and $8 \mathrm{~d}$ after inoculation. Each test consisted of 10 leaves of the non-transformed control and 25 leaves of the transgenic line. The tests were repeated twice. Data were analyzed statistically for analysis of variance using the PROC GLM program of SAS software (Statistical Analysis System, Cary, NC).

Pathogenicity with Sclerotium rolfsii. To evaluate the response to fungal pathogen $S$. rolfsii, transgenic plantlets and non-transformed control plantlets were grown for 6 months on the M15 medium with sub-culturing each month. The tissue-cultured plant materials used for the bioassay were $\approx 6 \mathrm{~cm}$ in height when inoculated with the fungal pathogen.

A sclerotium was isolated from a diseased taro plant in Waimea, HI. It was placed on a $9-\mathrm{cm}$ petri dish containing $10 \% \mathrm{~V} 8$ agar. Approximately 50 mature, brownish black sclerotia were formed after $21 \mathrm{~d}$.

In the first bioassay, one mature sclerotium was placed on the cut shoot base of each plantlet. Each inoculated plantlet was placed on a water-soaked filter paper in a sealed plastic bag (100\% humidity). For each test, three non-transformed plantlets and three transgenic plantlets were inoculated. The test was repeated four times. After inoculation, the plantlets were observed daily for lesion initiation and extension. The lengths of the necrotic lesions on shoots of non-transformed plantlets and transgenic plantlets were measured $6 \mathrm{~d}$ after inoculation. Data were analyzed statistically as described earlier.

In a second bioassay, tissue-cultured plantlets were acclimatized and then planted in $10-\mathrm{cm}$ diameter pots containing a peat-based medium. They were grown for 6 months under controlled, environmental conditions as described earlier. The plants were inoculated with $S$. rolfsii by removing the plant from the pot and placing 30 mature sclerotia against the roots in the potting medium. The plant was placed back into the pot, and a plastic bag was used to cover the whole plant to maintain high moisture levels. On Days 3, 7, and 14 after inoculation, the plants were removed from pots and photographed. Root infection was scored on the visible surfaces by visually estimating the percentage of the root system with lesions. Three non-transformed plants and three transformed plants were selected for each test, and the test was repeated three times. Data were analyzed statistically as described earlier.

\section{Results}

Initiation of calluses. Of over 40 media tested (Table 1), calluses of different colors and textures were induced in 12 media (Table 2). For cv. Bun Long, soft, yellowish white calluses were initiated after shoot tip explants were grown for 8 weeks on MS medium supplemented with $2 \mathrm{mg} \cdot \mathrm{L}^{-1} \mathrm{BA}$ and $1 \mathrm{mg} \cdot \mathrm{L}^{-1}$ NAA (M5 medium). These calluses could be maintained on the same medium for 3 to 4 months in the dark with sub-culturing once each month (Table 2). In contrast, no calluses of cv. Maui Lehua were initiated in M5 medium.

For both cultivars, a greenish yellow, compact callus was induced from shoot tip explants placed on MS medium (half-strength or 
full-strength) supplemented with 2,4-D (0.5 to $\left.3 \mathrm{mg} \cdot \mathrm{L}^{-1}\right)$ and either BA $\left(0.2\right.$ to $\left.3 \mathrm{mg} \cdot \mathrm{L}^{-1}\right)$ or kinetin (1 to $8 \mathrm{mg} \cdot \mathrm{L}^{-1}$ ) (M23 to M25, M38 to M44 media). In addition, a soft, yellowish white callus was induced from shoot tip explants of both cultivars placed on MS medium supplemented with $1 \mathrm{mg} \cdot \mathrm{L}^{-1}$ kinetin and $1.5 \mathrm{mg} \cdot \mathrm{L}^{-1} \mathrm{NAA}$ (M35 medium); however, both shoots and roots were produced among callus tissues, resulting in non-uniform, intractable transformation targets.

Regeneration of shoots. Calluses were transferred to the same callus initiation medium, hormone-free MS medium (M0), or MS medium supplemented with BA (M14, M15, or M16). More than eight multiple shoots could be induced on calluses of $\mathrm{cv}$. Bun Long that developed in M5 medium after transfer to M14, M15, or M16 media (shoot regeneration media). In contrast, if calluses were placed on M5 or M0 media, only a few shoot tips were formed (zero to three shoot tips). Multiple shoots developed in $\approx 2$ weeks on the medium with $8 \mathrm{mg} \cdot \mathrm{L}^{-1} \mathrm{BA}$ (M16); however, the shoot morphology was abnormal. Multiple, normal shoots were induced on either solid or liquid M15 media, and growth was faster than on the M14 medium, indicating that the M15 medium was superior for multiple shoot production. Alternating calluses between M5 and M15 media every 2 weeks for the first 2 months increased multiple shoot production, and an average of 12 shoots could be formed from each regenerative callus (Fig. 1).

Calluses of cv. Bun Long or cv. Maui Lehua that were formed in media containing 2,4-D (M23 to M25, M38 to M44 media) did not produce shoots after transfer to hormonefree MS medium (M0) or shoot regeneration media (M14, M15, or M16). Calluses of cv. Bun Long or cv. Maui Lehua that were induced in M35 medium formed a low number of regenerated shoots after transfer to shoot regeneration media.

Development of a transformation system. The soft, yellowish white calluses of cv. Bun Long that were induced on M5 medium were selected for further study as a result of their ability to regenerate shoots. A total of 30 pieces of calluses $(\approx 10 \%$ of the original calluses) survived and grew well on the selection media. These 30 calluses were screened using PCR analysis, and two PCR-positive callus lines showed the unique 540 bp ricchill gene fragment (Fig. 2A). Both callus lines were transferred to regeneration medium and two shoot lines were produced.

These two shoot lines were screened using PCR analysis, but only one shoot line was PCR-positive with the $540 \mathrm{bp}$ ricchill gene fragment (Fig. 2A). In the histochemical GUS assay, leaf and stem tissues from the PCRpositive transgenic shoot line (T1) exhibited the characteristic blue color, whereas leaf and stem tissues from the non-transformed plant did not (Fig. 3). In addition, RT-PCR for the chitinase gene was positive in the PCR-positive transgenic shoot line (Fig. 2B), confirming the expression of the ricchil1 gene. These results indicated that the reporter gus gene had been

Table 2. Characteristics of callus induced in taro cv. Bun Long by five callus initiation media consisting of full-strength Murashige and Skoog media supplemented by varying concentrations and types of phytohormones. $^{\mathrm{z}}$

\begin{tabular}{|c|c|c|c|c|c|c|}
\hline Media & Phytohormone $\left(\mathrm{mg} \cdot \mathrm{L}^{-1}\right)^{\mathrm{y}}$ & $\begin{array}{l}\text { Callus } \\
\text { growth }^{\mathrm{x}}\end{array}$ & $\begin{array}{c}\text { Growth } \\
\text { rate }^{w}\end{array}$ & Color & Texture & Regeneration $^{\vee}$ \\
\hline$\overline{\mathrm{M} 5}$ & $\mathrm{BA}(2)+\mathrm{NAA}(1)$ & Good & Fast & Yellowish white & Soft & High \\
\hline M23 & $\mathrm{BA}(0.2)+2,4-\mathrm{D}(0.5)$ & Good & Slow & Greenish yellow & Compact & No \\
\hline M24 & $\mathrm{BA}(1)+2,4-\mathrm{D}(3)$ & Good & Fast & Greenish yellow & Compact & No \\
\hline $\mathrm{M} 25^{\mathrm{u}}$ & $\mathrm{BA}(3)+2,4-\mathrm{D}(3)$ & Good & Fast & Greenish yellow & Compact & No \\
\hline M35 & Kinetin (1) + NAA (1.5) & Non-uniform & Fast & Yellowish white & Soft & Low \\
\hline
\end{tabular}

${ }^{z}$ Calluses were then tested on three shoot regeneration media for ability to produce shoots.

${ }^{\mathrm{y}} \mathrm{BA}=$ benzyladenine; NAA = napthaleneacetic acid; 2,4-D = 2,4-dichlorophenoxyacetic acid; parentheses contain concentrations in $\mathrm{mg} \cdot \mathrm{L}^{-1}$.

${ }^{\mathrm{x}}$ Good growth indicates uniform production of callus tissues; non-uniform indicates production of roots and shoots among callus tissues.

${ }^{\text {w}}$ Fast growth rate indicates production of usable callus tissues within 3 to 4 months; slow growth indicates insufficient production of usable callus tissues during this time period.

${ }^{v}$ High regeneration indicates that more than eight multiple shoots could be induced from one callus after transfer to shoot regeneration media; low regeneration indicates that only one or two shoots could be induced after transfer to shoot regeneration media.

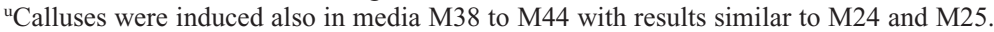

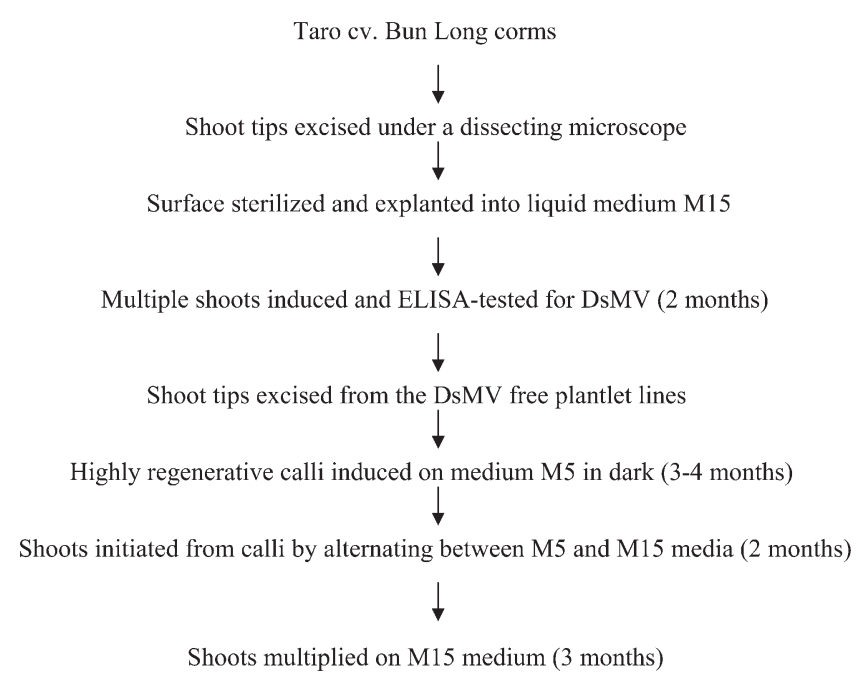

Fig. 1. The flow chart of callus initiation and regeneration of taro cv. Bun Long. Note that the entire cycle takes 10 to 11 months.

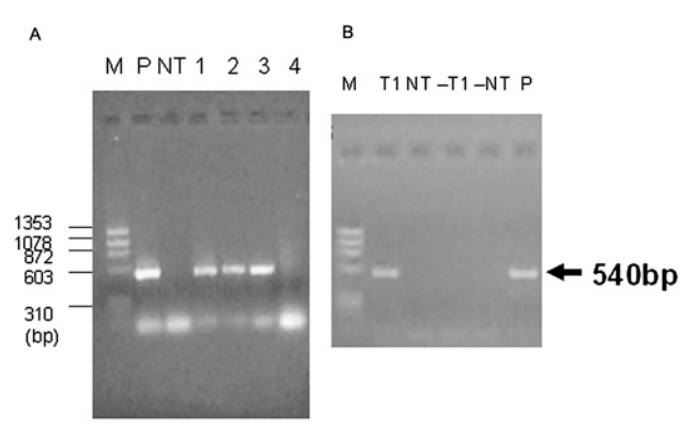

Fig. 2. (A-B) Polymerase chain reaction (PCR) and reverse transcription (RT)-PCR analysis of transformed lines with the ricchil1 gene. (A) Agarose gel electrophoresis of PCR amplification of the ricchil1 unique 540-bp fragment. (B) Agarose gel electrophoresis of RT-PCR products using the ricchil1 gene primer. Lanes in $\mathbf{A}: \mathbf{M}=$ molecular size marker; $\mathrm{P}=$ plasmid control; $\mathrm{NT}=$ nontransformed control; one to two two transformed callus lines (1-T1 callus, 2 - T2 callus); three to four two shoot lines derived from $\mathrm{T} 1$ and $\mathrm{T} 2$ callus, respectively. Lanes in $\mathbf{B}$ : $\mathrm{T} 1=$ transgenic line one; $\mathrm{NT}=$ non-transformed control; $-\mathrm{T} 1=$ transgenic line one without $\mathrm{RT}$; $-\mathrm{NT}=$ non-transformed control without RT; P = plasmid control.

integrated into the taro genome and successfully expressed in this one transgenic line.

The two PCR-positive callus lines were analyzed by Southern blot hybridization.
Digestion of the extracted DNA with the restriction enzyme Bam $\mathrm{HI}$ released a $1.9-\mathrm{kb}$ fragment corresponding to the ricchill gene from the transformation plasmid pBI121/ 
ricchil1 and PCR-positive line (T1) plants (Fig. 4A). No gene fragment was observed in the non-transformed control plants or the PCR-negative shoot line (T2) plants. EcoRI restriction digests of genomic DNA extracted from the PCR-positive plant line (T1) yielded 13 multiple bands (Fig. 4B). Because EcoRI only has one digestion site in the T-DNA containing the ricchill gene, multiple bands in the Southern blot indicated a multiple copy transgene insertion into the taro genome.

Pathogenicity of Phytophthora colocasiae. Transgenic plants grown for $30 \mathrm{~d}$ in pots were visually similar to non-transformed control plants. At $4 \mathrm{~d}$ after inoculation with oomycete $P$. colocasiae, the average diameter of the infected leaf was not significantly different between transgenic plants and non-transformed control plants (Fig. 5, left).

Pathogenicity of Sclerotium rolfsii. In the first bioassay, transformed and non-transformed tissue-cultured plantlets were inoculated with the fungus $S$. rolfsii. Necrotic lesions were visible on non-transformed plantlets $2 \mathrm{~d}$ after inoculation. In contrast, necrotic lesions on the transgenic plantlet line were visible only 3 to $4 \mathrm{~d}$ after inoculation. The lengths of lesions measured at $6 \mathrm{~d}$ after inoculation were significantly shorter $(37 \% ; P<0.05)$ in the transgenic line with the chitinase gene ricchill compared with those of the non-transformed plantlet controls (Fig. 5, right). The non-transformed plantlets died at $6 \mathrm{~d}$ after inoculation; in contrast, the transgenic plantlets died at $8 \mathrm{~d}$ after inoculation.

In the second bioassay, 6-month-old transformed and non-transformed plants in pots were inoculated with $S$. rolfsii. Necrotic lesions were visible on the roots of nontransformed plants $3 \mathrm{~d}$ after inoculation. In contrast, necrotic lesions on the roots of the transgenic plant line were visible only $7 \mathrm{~d}$ after inoculation. On Days 3, 7, and 14, root lesion levels were scored on non-transformed plants at $30 \%, 70 \%$, and $100 \%$, respectively (Fig. 6A-B). In contrast, in transformed plants, no root lesions were observed $3 \mathrm{~d}$ after inoculation, and root lesion levels were scored at $20 \%$ and $30 \%$ on Days 7 and 14 , respectively (Fig. 6A-B). The percentage of the root system with lesions at $14 \mathrm{~d}$ after inoculation was significantly smaller $(30 \%$;

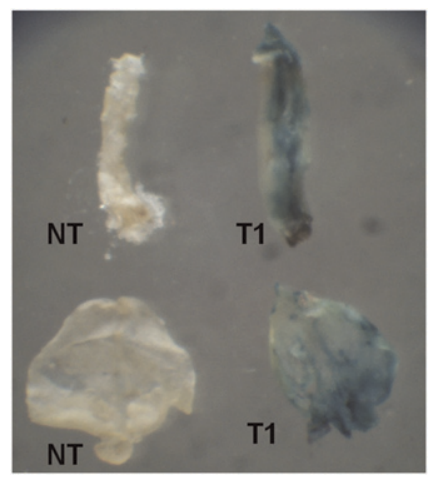

Fig. 3. Histochemical GUS assay of the stem (top) and leaf cuttings (bottom) of the transgenic line one (T1) and non-transformed control (NT).
$P<0.05)$ in the transgenic line compared with that of the non-transformed control (Fig. 6B).

Mycelia reached the plant stems by $7 \mathrm{~d}$ after inoculation of both non-transformed plants and transformed plants. Stems of non-transformed plants exhibited lesions by $7 \mathrm{~d}$, and the whole plant died by $14 \mathrm{~d}$ (Fig. $6 \mathrm{~A})$. In contrast, the stems of transformed plants were not infected by these mycelia at 7 or $14 \mathrm{~d}$ after inoculation. Lesions in stems of transgenic taro were evident by $30 \mathrm{~d}$ and plants died by $50 \mathrm{~d}$ or greater than threefold longer durations compared with non-transformed control plants.

\section{Discussion}

Development of a regeneration system. To insert transgenes into totipotent cells and then recover whole plants, methods for callus initiation and subsequent plantlet regeneration are needed. In this study, we tested over 40 media for callus initiation and five media for shoot regeneration and found one superior

$$
\text { A }
$$

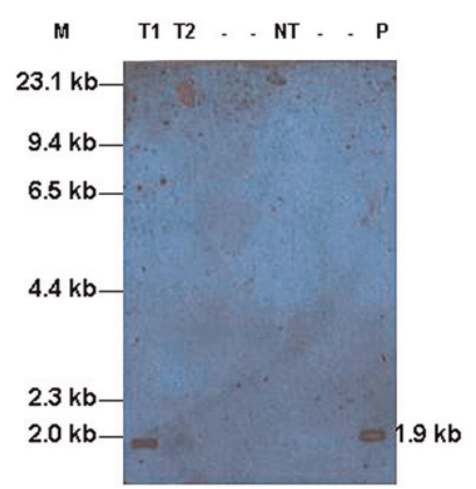

combination to produce regenerable calluses for taro cv. Bun Long that differs from previously published methods. The best callus initiation media for cv. Bun Long was full-strength MS medium supplemented with $2 \mathrm{mg} \cdot \mathrm{L}^{-1} \mathrm{BA}$ and $1 \mathrm{mg} \cdot \mathrm{L}^{-1} \mathrm{NAA}$. The best shoot regeneration medium consisted of fullstrength MS medium with $4 \mathrm{mg} \cdot \mathrm{L}^{-1} \mathrm{BA}$.

Fukino et al. (2000) found that a similar combination of BA and NAA in LS medium initiated callus in the triploid taro cultivar cv. Eguimo; however, the callus of this cultivar regenerated in hormone-free LS medium. For callus of cv. Bun Long initiated on M5 medium to regenerate, cytokinins such as BA were required for shoot initiation in the regeneration media (M14 to M16). This regeneration system appears to be specific for the taro cv. Bun Long, because attempts to produce regenerable callus from cv. Maui Lehua were not successful.

Yam et al. (1990) used TE to produce regenerable calluses in taro cv. Akalomamale; however, his method did not work for
B

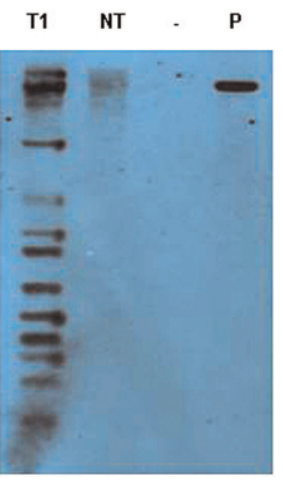

Fig. 4. (A-B) Southern blot analysis of genomic DNA from taro leaves. (A) DNA doubly digested with Bam HI that cuts on both sides of the transgene to release a 1.9-kb fragment with homology to the ricchill gene. (B) DNA singly digested with EcoRI that cuts once in the T-DNA region outside the ricchil1 gene. Lanes in $\mathbf{A}: \mathbf{M}=$ molecular marker; $\mathrm{T} 1$ = polymerase chain reaction (PCR)-positive T1 plants; T2 = PCR-negative T2 plants; NT = non-transformed control taro; $\mathrm{P}=$ plasmid pBI121/ ricchi111 DNA. Lanes in B: T1 = PCR-positive T1 plants; NT = non-transformed control taro; P = plasmid pBI121/ricchi111 DNA.

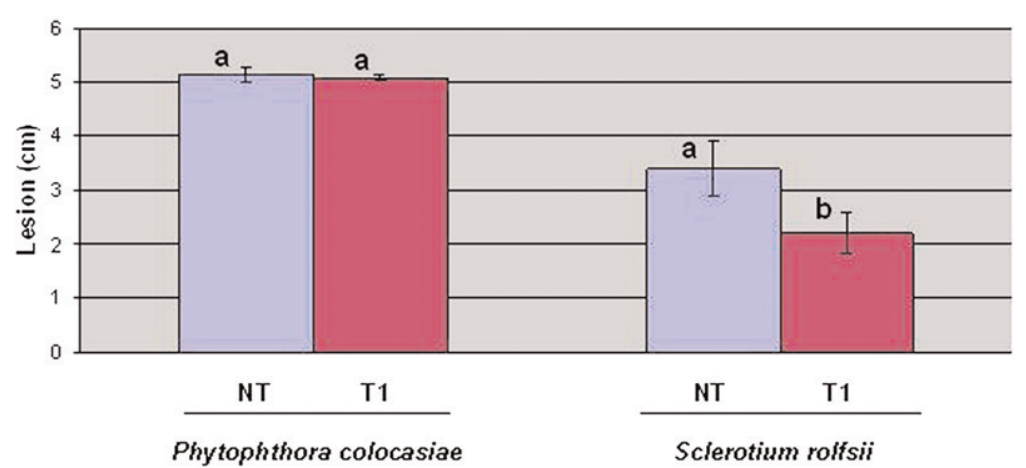

Fig. 5. (Left) Lesion diameter (cm) on Phytophthora colocasiae-inoculated leaves of non-transformed control plantlets (NT) and transgenic line T1 (T1) plantlets measured $4 \mathrm{~d}$ after inoculation. Graph bars represent the mean \pm SD values of two replicates (each replicate consisted of $10 \mathrm{NT}$ and $25 \mathrm{~T} 1$ leaves). Same letters indicate no significant differences $(P<0.05)$ between NT and T1. (Right) Lesion length $(\mathrm{cm})$ on Sclerotium rolfsii-inoculated shoots of non-transformed control plantlets (NT) and transgenic line T1 plantlets (T1) measured $6 \mathrm{~d}$ after inoculation. Graph bars represent the mean \pm SD values of four replicates (each replicate consisted of three NT and three T1 plantlets). Different letters (a, b) indicate significant differences $(P<0.05)$ between NT and T1. 

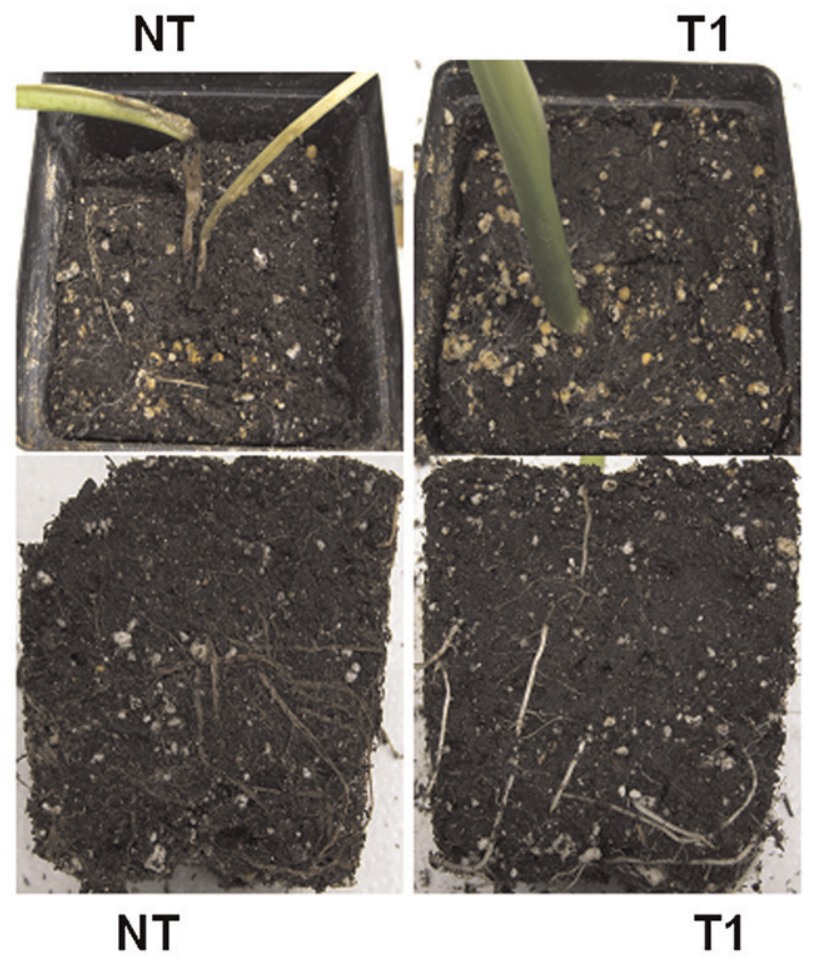

B

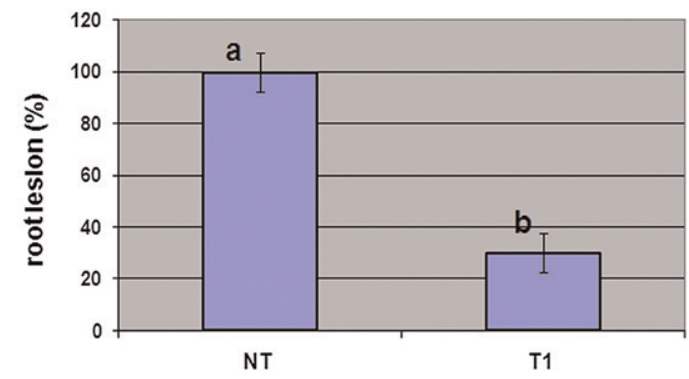

Fig. 6. (A-B) Bioassay of 6-month-old taro plants of the transgenic line one (T1) and non-transformed plant controls (NT) inoculated with Sclerotium rolfsii at $14 \mathrm{~d}$ after inoculation. (A) Necrotic lesions of roots and shoots of NT plants were visible. Necrotic lesions of T1 roots were visibly smaller than those of NT roots, and no stem lesions were observed. (B) The percentage of the root system with lesions of non-transformed control plants (NT) and transgenic line T1 plants (T1) visually estimated at $14 \mathrm{~d}$ after inoculation. Graph bars represent the mean \pm SD values of three replicates (each replicate consisted of three NT and three T1 plants). Different letters $(\mathrm{a}, \mathrm{b})$ indicate significant differences $(P<0.05)$ between NT and T1.

initiation of callus in either of the two taro cultivars used in this study. Similarly, 2,4-D was used to produce regenerable callus for taro cvs. Dotare and Eguimo (Malamug et al., 1992; Murakami et al., 1995). Although we were able to produce callus using 2,4-D on both taro cultivars, we were unable to regenerate shoots from these calluses. Evidently, the effectiveness of varying combinations and concentrations of phytohormones to produce regenerable calluses differ between taro genotypes.

Interestingly, Deo et al. (2009) reported that calluses of three taro cultivars (cvs. CPUK, CK-07, and THA-07) that formed in half-strength MS medium with $2.0 \mathrm{mg} \cdot \mathrm{L}^{-1}$ 2,4-D would develop into regenerable, somatic embryos when sub-cultured in halfstrength MS medium containing $1.0 \mathrm{mg} \cdot \mathrm{L}^{-1}$ thidiazuron (cytokinin). This method of Deo et al. (2009) should be tested on other taro cultivars that fail to respond to methods presented here.

Transformation with a rice chitinase gene. Over 30 calluses survived on $50 \mathrm{mg} \cdot \mathrm{L}^{-1}$ geneticin, but only two callus lines showed positive PCR results. Two shoot lines were regenerated from these callus lines; however, shoots from only one of these transformed lines were PCR-positive. These results indicated that at the callus level, some transformed colonies were chimeric, escaping from selection stress but then reverting back to a nontransformed state. Therefore, to confirm that the ricchill gene has been successfully introduced into the genome, both PCR and Southern blot analyses should be conducted at the plant level.
Disease resistance. In the bioassay conducted on whole plants grown in pots, the taro plant line transformed with the chitinase gene ricchill through particle bombardment did not exhibit increased resistance to $P$. colocasiae. This result was not unexpected because this taro pathogen is an oomycete and its cell walls contain much less chitin than those of fungal pathogens (Yan et al., 2008). Interestingly, Sharma et al. (2009) showed that a putative chitinase gene was upregulated when taro was inoculated with $P$. colocasiae. Perhaps, a naturally occurring chitinase gene from taro is involved in resistance to this oomycete pathogen. Future research needs to investigate naturally occurring chitinases found in the taro germplasm and their effectiveness in enhancing disease resistance.

Comparison of two transformation methods. Only one stable, transgenic line was produced through particle bombardment from 1350 pieces of callus $(60 \mathrm{~g})$ or a transformation efficiency of less than $0.1 \%$. Similarly, Fukino et al. (2000) produced only two transgenic lines from a total of $192 \mathrm{~g}$ of calluses with an efficiency rate of less than $1 \%$. In contrast, He et al. (2008) produced six independent transgenic lines from 200 pieces of callus (8 g) through Agrobacterium-mediated transformation or a transformation efficiency of $3 \%$. Evidently, Agrobacterium-mediated transformation of taro is a more efficient method of genetic transformation.

In this study, we produced a single, stable transformant line with 13 copies of the transgene. He et al. (2008) reported that Agrobacterium-mediated transformation produced three lines with a single copy of the transgene and the other three lines had two or three copies. Multiple copies of genes are thought to be undesirable as a result of recombination, instability, and gene silencing (Veluthambi et al., 2003). Interestingly, despite the multiple copies of the transgenes, the transgenic taro line in this study still showed significant, although modest, resistance to the fungal pathogen $S$. rolfsii. Perhaps, insertion of additional PR genes could improve disease resistance as has been found by other researchers (Jayaraj and Punja, 2007; Sridevi et al., 2008).

Future research. Although genetic transformation of taro has the potential to improve resistance to diseases that have devastated taro production in many countries, such research in Hawaii has been suspended in part because of bans passed by the County Councils of Hawaii (Armstrong, 2008) and Maui (Tanji, 2009). The Legislature in Hawaii ranked first in the nation during 2005 to 2006 in the number of bills dealing with the regulation of agricultural biotechnology (44 bills or $34 \%$ of all such bills in the United States; Pew Initiative on Food and Biotechnology, 2007). As a result of these bans and recent controversies, future taro research will focus on identifying naturally occurring disease resistance genes in taro (such as chitinase) and genetic markers associated with them. It may be possible to use marker-assisted 
selection to accelerate the conventional breeding of taro for improved disease resistance.

\section{Literature Cited}

Altpeter, F., N. Baisakh, R. Beachy, R. Bock, T. Capell, P. Christou, H. Daniell, K. Datta, S. Datta, P.J. Dix, C. Fauquet, N. Huang, A. Kohli, H. Mooibroek, L. Nicholson, T.T. Nguyen, G. Nugent, K. Raemakers, A. Romano, D.A. Somers, E. Stoger, N. Taylor, and R. Visser. 2005. Particle bombardment and the genetic enhancement of crops: Myths and realities. Mol. Breed. 15:305327.

Armstrong, J. 2008. GMO taro, coffee banned: Council overrides mayor's veto by unanimous vote. Hawaii Tribune Herald. 14 Nov. 2008. p. A-1-A-6.

Brooks, F.E. 2000. Detached-leaf bioassay for evaluating taro resistance to Phytophthora colocasiae. Plant Dis. 92:126-131.

Cho, J.J., R.A. Yamakawa, and J. Hollyer. 2007. Hawaiian Kalo, past and future. Univ. of Hawaii, College of Trop. Agr. and Human Resources. SA-1.

Datta, K., Z. Koukolikova-Nicola, N. Baisakh, N. Oliva, and S.K. Datta. 2000. Agrobacteriummediated engineering for sheath blight resistance of indica rice cultivars from different ecosystems. Theor. Appl. Genet. 100:832-839.

Deo, P.C., R.M. Harding, M. Taylor, A.P. Tyagi, and D.K. Becker. 2009. Somatic embryogenesis, organogenesis and plant regeneration in taro (Colocasia esculenta var. esculenta). Plant Cell Tissue Organ Cult. 99:61-71.

Food and Agriculture Organization of the United Nations. 2009. 28 Dec. 2009. <http://fastat.fao. org/>.

Fukino, N., K. Hanada, and H. Ajisaka. 2000. Transformation of taro (Colocasia esculenta Schott) using particle bombardment. JARQ 34:159-165.

Gooday, G.W. 1990. The ecology of chitin degradation, p. 387-430. In: Marshall, K.C. (ed.). Advances in microbial ecology II. Plenum Press, New York, NY.

Grison, R., B.B. Grezes, M. Schneider, N. Lucante, L. Olsen, J.J. Leguay, and A. Toppan. 1996. Field tolerance to fungal pathogens of Brassica napus constitutively expressing a chimeric chitinase gene. Nat. Biotechnol. 14:643-646.

Hartman, R.D. 1974. Dasheen mosaic virus and other phytopathogens eliminated from caladium, taro, and cocoyam by culture of shoot tips. Phytopathol. 64:237-240.
He, X., S.C. Miyasaka, M.M.M. Fitch, P.H. Moore, and Y.J. Zhu. 2008. Agrobacterium tumefaciensmediated transformation of taro [Colocasia esculenta (L.) Schott] with a rice chitinase gene for improved tolerance to a fungal pathogen Sclerotium rolfsii. Plant Cell Rep. 27: 903-909.

Jayaraj, J. and Z.K. Punja. 2007. Combined expression of chitinase and lipid transfer protein genes in transgenic carrot plants enhances resistance to foliar fungal pathogens. Plant Cell Rep. 26:1539-1546.

Koike, S.T., P. Gladders, and A.O. Paulus. 2006. Vegetable diseases: A color handbook. Academic Press, San Diego, CA. p. 340-341.

Lin, W., C.S. Anuratha, K. Datta, I. Potrykus, S. Muthukrishnan, and S.K. Datta. 1995. Genetic engineering of rice for resistance to sheath blight. BioTechnol. 13:686-691.

Malamug, J.J., H. Inden, S. Yazawa, and T. Asahira. 1992. Plantlet generation from taro (Colocasiae esculenta Schott) callus. J. Jpn. Soc. Hort. Sci. 60:935-940.

Maximova, S.N., J.P. Marelli, A. Young, S. Pishak, J.A. Verica, and M.J. Guiltinan. 2006. Overexpression of a cacao class I chitinase gene in Theobroma cacao L. enhances resistance against the pathogen, Colletotrichum gloeosporioides. Planta 224:740-749.

Miller, P.M. 1955. V-8 juice agar as a general purpose medium for fungi and bacteria. Phytopathol. 45:461-462.

Miyasaka, S.C., J.R. Hollyer, and L.S. Kodani. 2001. Mulch and compost effects on yield and corm rots of taro. Field Crops Res. 71:101-112.

Murakami, K., M. Kimura, and S. Matsubara. 1995. Plant regeneration from protoplasts isolated from callus of taro (Colocasia esculenta Schott). J. Jpn. Soc. Hort. Sci. 63:773-778.

Murashige, T. and F. Skoog. 1962. A revised medium for rapid growth and bioassays with tobacco tissue cultures. Physiol. Plant. 15: 473-497.

Parkinson, S. 1984. The contribution of aroids in the nutrition of people in the South Pacific, p. 215-242. In: Chandra, S. (ed.). Edible aroids. Clarendon Press, Oxford, UK.

Pew Iniative on Food and Biotechnology. 2007. Factsheet: State legislative activity related to Agricultural biotechnology in 2005-2006. 10 Feb. 2010. <http://www.pewtrusts.org/uploaded Files/wwwpewtrustsorg/Reports/Food_and_ Biotechnology/PIFB_State_Legislature_20052006Session.pdf>.
Plucknett, D.L., R.S. de La Pena, and F. Obrero. 1970. Taro (Colocasia esculenta). Field Crop Abstracts. 23:413-426.

Revill, P.A., G.V.H. Jackson, G.J. Hafner, I. Yang, M.K. Maino, M.L. Dowling, L.C. Devitt, J.L. Dale, and R.M. Harding. 2005. Incidence and distribution of viruses of taro (Colocasia esculenta) in Pacific Island countries. Australas. Plant Pathol. 34:327-331.

Schlumbaum, A., F. Mauch, U. Vogeli, and T. Boller. 1986. Plant chitinases are potent inhibitors of fungal growth. Nature 324:365-367.

Sharma, K., A.K. Mishra, and R.S. Misra. 2009. Identification and characterization of differentially expressed genes in the resistance reaction in taro infected with Phytophthora colocasiae. Mol. Biol. Rep. 36:1291-1297.

Sridevi, G., C. Parameswari, N. Sabapathi, V. Raghupathy, and K. Veluthambi. 2008. Combined expression of chitinase and $\beta-1,3-$ glucanase genes in indica rice (Oryza sativa L.) enhances resistance against Rhizoctonia solani. Plant Sci. 175:283-290.

Tanji, M. 2009. Council approves ban on GMO taro. Maui News. 10 Feb. 2010. <http://www. mauinews.com/page/content.detail/id/524344. html>.

Trujillo, E.E., T. Menezes, and C. Cavaletto. 2002. Promising new taro cultivars with resistance to taro leaf blight: 'Pa 'lehua', 'Pa 'akala', and 'Pauakea'. Univ. of Hawai'i, Coll. of Trop. Agr. and Human Resources. NPH-7.

Uchida, J.Y., J.A. Silva, and C.Y. Kadooka. 2002. Improvements in taro culture and reduction in disease levels. Univ. of Hawai' $i$, Coll. of Trop. Agr. and Human Resources. PD-22.

Veluthambi, K., A.K. Gupta, and A. Sharma. 2003. The current status of plant transformation technologies. Curr. Sci. 84:368-378.

Yam, T.W., J.L.P. Young, K.P.L. Fan, and J. Arditti. 1990. Induction of callus from axillary buds of taro (Colocasia esculenta var. esculenta, Araceae) and subsequent plantlet regeneration. Plant Cell Rep. 9:459-462.

Yan, R.X., J.H. Hou, D.F. Ding, W.Q. Guan, C.Y. Wang, Z.Q. Wu, and M.G. Li. 2008. In vitro antifungal activity and mechanisms of action of chitinase against four plant pathogenic fungi. J. Basic Microbiol. 48:293-301.

Young, J.K. and B.K. Hwang. 1996. Purification, $\mathrm{N}$-terminal amino acid sequencing and antifungal activity of chitanases from pepper stems treated with mercuric chloride. Physiol. Mol. Plant Pathol. 48:417-432. 